ks. Grzegorz Barth

Katolicki Uniwersytet Lubelski Jana Pawła II

DOI: $10.15290 /$ std.2016.02.05

\title{
SAKRAMENTALNOŚĆ MAŁŻEŃSTWA W RELACJI DO EUCHARYSTII
}

\section{THE SACRAMENTALITY OF MARRIAGE IN RELATION TO EUCHARIST}

This text discusses the relationship between the sacrament of marriage and the Eucharist. The motive undertake this relationship was the last Synod of Bishops on the role of marriage and family in the world. The biggest controversy has raised the issue of "irregular" situation and therefore granting of the Holy Communion to persons who are in the second unity. In the first part, the author of the text presents the arguments of supporters and opponents granting of Holy Communion for such persons. Without going into comment regarding direct to each of the reasons, the author considers as essential the question of how one and the second option understands the current state of reflection as "impasse" and how much of a "impetus". In one and the other can to hide the real danger of the ideological thinking, leading to an impasse, and the chance to view something further and wider, and so the impetus for deeper and more responsible reflections. These are the issues of mercy, sin, the law of growth and analysis of specific experiences. In the second part of the text, the author draws a theological horizon to link theology of creation with science of salvation (sacramentology) and, consequently, more theological than ever juridically-legalistic way to justify the sacramentality. It's about deeper showing into symbolism of the sacrament of marriage as a medium of the saving content. Also presents the four dimensions of the correlation between the marriage and the Eucharist: spousal, spiritual, communial and covenant. They are crucial to the renewal of the theology of the sacrament of marriage.

Key words: marriage, sacrament, Eucharist, Francis, Synod. 
Ostatni Synod Biskupów na temat małżeństwa i rodziny, którego owocem jest ogłoszona, 8 kwietnia 2016 roku, przez papieża Franciszka adhortacja Amoris laetitia, stał się w środowisku kościelnym i teologicznym impulsem ożywiającym dyskusję wokól chrześcijańskiej wizji małżeństwa i rodziny. Komentarze, opinie, a nawet kontrowersje towarzyszące obradom synodalnym, jak bardzo spolaryzowane są stanowiska na temat rozumienia i znaczenia sakramentalności małżeństwa. W wielu wypowiedziach wybrzmiewał ton mocnej krytyki, sugerującej odejście Synodu od Tradycji/prawowiernego nauczania Kościoła oraz uleganie naciskom laickiej i antymałżeńskiej ideologii. Inni z kolei twierdzili, że postawa Ojców synodalnych, a zwłaszcza Franciszka to głos rozsądku i wyraźnej troski w obliczu rzeczywistych trudności, z jakimi mierzy się dziś chrześcijańskie małżeństwo i rodzina. Wśród licznych postulatów posynodalnych pojawiły się sugestie, aby właśnie teologowie podjęli się nowego przemyślenia istoty sakramentu małżeństwa w kontekście przemian i doświadczeń społeczno-kulturowych, na które wskazał Synod. Odmienne opinie dotyczyły najczęściej relacji między obu sakramentami, zwłaszcza w sytuacjach tzw. nieregularnych, a więc odnoszących się do osób rozwiedzionych i żyjących w ponownych związkach w kontekście możliwości przystępowania przez nie do Eucharystii. Istotnie, rozbieżność w ocenie podejść duszpasterskich stała się „papierkiem lakmusowym” deficytów w obrębie solidnej podstawy teoretyczno-teologicznej rozumienia istoty sakramentalności i wynikających $z$ niego praktycznych konsekwencji. Wychodząc naprzeciw zaistniałej sytuacji, niniejsze opracowanie stanowi próbę uchwycenia tej złożonej, zarówno od strony teoretyczno-teologicznej, jak i praktycznej (pastoralnej i społeczno-kulturowej), relacji między sakramentem małżeństwa i Eucharystii. Oznacza to zatem, że przedsięwzięcie to stanowi raczej wskazanie określonych pól i aspektów, w obrębie których winna się rozpocząć lub być kontynuowana solidna refleksja teologiczna nad rozumieniem sakramentalności, a nie gotowych propozycji ich rozwiązań. Poważne braki w tej materii dały o sobie znać nie tylko w kontekście debaty synodalnej, ale wybrzmiewają także obecnie w poadhortacyjnych komentarzach; zdaje się, że dostrzegają je także teologowie, wykładający sakramentologię oraz duszpasterze.

Zamiar zmierzenia się $z$ tak zasygnalizowanym problemem będzie obejmował dwa zasadnicze etapy: najpierw zwięzłe i panoramiczne scharakteryzowanie poglądów dotyczących wspomnianych sytuacji „nieregularnych” [I], a następnie nakreślenie teologicznego horyzontu [II], umożliwiającego: ściślejsze niż dotąd powiązanie teologii stworzenia z nauką o Zbawieniu (sakramentologią), a w konsekwencji bardziej teologiczny niż dotąd jurydyczno-legalistyczny 
sposób uzasadnienia ${ }^{1}$, przez niektórych uznawany za jedynie symboliczno- estetyczny, relacji między sakramentem małżeństwa a Eucharystią. Warto nadmienić, że pierwotna wersja niniejszego tekstu powstała krótko przed obradami XIV Zgromadzenia Zwyczajnego Synodu Biskupów, które obradowało w dniach 4-25 października 2015 roku oraz przed ogłoszeniem adhortacji Amoris laetitia, co może mieć istotne znaczenie, zarówno dla oceny jego aktualności, jak i formy prezentacji. Konkretniej: przywoływane gdzieniegdzie w tekście fragmenty wspomnianej adhortacji, która - rzecz jasna - rzuca nowe i ważne światło na interpretację podejmowanej tu sprawy, mają charakter komentarza, którego nie można było pominąć. Omówieniu sytuacji tzw. nieregularnych, bezpośrednio związanych z rozumieniem relacji małżeństwo - Eucharystia, papież Franciszek poświęcił VIII rozdział adhortacji (pkt. 291-312), w którym dominuje nastawienie bardziej pastoralne i praktyczne, niż doktrynalne i normatywne. Bez wątpienia, dokument również w tym aspekcie domaga się oddzielnego krytycznego opracowania.

\section{Sytuacje „nieregularne” - impas czy impuls?}

Problem przystępowania do Komunii św. przez osoby rozwiedzione i żyjące w innych związkach jest bardzo trudny i wieloaspektowy. Z jednej strony - głęboka symbolika sakramentu małżeństwa oraz waga Eucharystii jako daru największego, a z drugiej - złożona sytuacja egzystencjalna rozwiedzionych osób, szczerze religijnych. Do tego dochodzi słabnące coraz bardziej wartościowanie obu sakramentów. Jest ono wyrazem nie tyle bezpośredniego zaniku wiary, co jest wywołane czynnikami, które dotyczą głębokich zmian społeczno-kulturowych, mających bezpośrednie i decydujące przełożenie na ich charakter sakramentów. W odniesieniu do zasygnalizowanej powyżej trudności, warto chyba zauważyć, że ci, którzy akcentują pierwszy aspekt problemu, widzą rozwiązanie zaistniałego stanu rzeczy w spojrzeniu „wstecz”, a więc jakiekolwiek zmiany w dyscyplinie Kościoła co do oceny sytuacji osób rozwiedzionych, będących w powtórnym związku i pragnących przystąpić do Eucharystii, stoi w jaskrawej sprzeczności z długim i uświęconym tradycją nauczaniem kościelnym na temat małżeństwa. Mogą one - ich zdaniem - okazać się jedynie ciosem wymierzonym w godność obu sakramentów, co w konsekwencji - na poziomie ich odbioru i przeżywania przez wiernych - doprowadzi do rozmycia jasności doktryny i degradacji życia sakramentalnego. Reprezentanci drugiego nastawienia, kierowani trzeźwą oceną sytuacji tzw. nieregularnych, jednak coraz powszechniejszych (stających się niepisaną „normą”), ale i złożonych

Warto zwrócić uwagę, że użycie słowa: „niedopuszczanie” w kontekście osób niemogących przystąpić do Komunii św., wskazuje na jurydyczno-formalny ton języka teologicznego. 
pod względem antropologicznym, psychologicznym, społeczno-kulturowym, religijnym czy instytucjonalnym, jedyną możliwość rozwiązania problemu widzą w spojrzeniu „wprzód”, domagając się wprost rozluźnienia dyscypliny Kościoła. Jedni i drudzy, rzecz jasna, żeby dowieść swoich racji, przywołują różnego rodzaju argumenty, które należy przedstawić na wstępie jakiejkolwiek dyskusji jako niezbędne jej tło. Wszystkie one bowiem uzmysławiają rangę i zakres poruszanego problemu, a mianowicie, że jego rzeczywiste i należyte rozważenie nie może być przyćmione, a tym bardziej zastąpione, rozstrzygnięciami o charakterze prawno-kanonicznym, a nawet stricte doktrynalnym ${ }^{2}$. Musi ono uwzględniać wszystkie dostępne i możliwe do rozważenia poziomy i aspekty sprawy, dochodzące do głosu po obu stronach sporu.

\section{Racje zwolenników niedopuszczania do Eucharystii}

1. Racje dotyczące natury Kościoła oraz charakteru jego nauczania. Utrzymanie dyscypliny w tym zakresie dotyczy bezpośrednio prawa Bożego, opierającego się na świadectwie Pisma Świętego, dlatego Kościół nie posiada takiej władzy, aby osobom rozwiedzionym żyjącym i współżyjącym w niesakramentalnych związkach udzielać sakramentalnego rozgrzeszenia i Komunii św. Dalej, opiera się ona na mocy konstytutywnego związku między uczestnictwem w Eucharystii i komunią z Kościołem a jego nauczaniem o nierozerwalności małżeństwa ${ }^{3}$. Wśród wymienianych racji istnieją też te, dotyczące struktury Kościoła. W sytuacji pojawiających się rozbieżności między autorytatywnym nauczaniem Magisterium Ecclesiae a jego interpretacją na poziomie Kościołów lokalnych, kard. G. L. Müller przypomniał, że „konferencje episkopatu są wyrazem kolegialności biskupów na szczeblu krajowym, kulturowym czy językowym, ale są organizacją praktyczną. Kościół katolicki istnieje jako Kościół powszechny w komunii wszystkich biskupów w łączności z papieżem i pod jego przewodnictwem" ${ }^{4}$.

2. Sakramentalny charakter zarówno Eucharystii, jak i małżeństwa, stanowi podstawowy element całej konstrukcji kościelnej od początku.

Takie podejście zdaje się mieć na myśli Franciszek, kiedy stwierdza, że „zmiana antropologiczno-kulturowa wpływa dziś na wszystkie aspekty życia i wymaga podejścia analitycznego i zróżnicowanego". Franciszek, Amoris laetitia [dalej skrót: AL], Watykan 2016, nr 36.

3 Relatio synodi, III Nadzwyczajnego Zgromadzenia Ogólnego Synodu Biskupów, http:// episkopat.pl/dokumenty/6230.1,quot_Relatio_Synodi_quot_III_Nadzwyczajnego_Zgromadzenia_Ogolnego_Synodu_Biskupow.html, [dostęp: 28.04.2016], nr 52.

4 G. L. Müller, Nie można mieć dwóch żon, http://ekai.pl/wydarzenia/komentarze/x87756/ kard-muller-nie-mozna-miec-dwoch-zon/?print=1. [dostęp: 28.04.2016]. 
Jego pomniejszenie, a zwłaszcza odrzucenie, rujnuje całą logikę Kościoła katolickiego, strukturalną i duchową .

3. Argumentacja meta-teologiczna oparta na tezie, iż doktryna chrześcijańska nie jest „teorią” o rzeczywistości, ale „samą prawdą” objawioną. Dopiero z niej wynika postulat postępowania zgodny z zasadami tej rzeczywistości, przyjmując na siebie krzyż i konkretne problemy, które jej towarzyszą. Dyscyplina sakramentów jest tylko i wyłącznie wyrazem doktryny wiary i z tego względu nie może być z nią rozbieżna.

4. Semantyczne „osłabienie” rangi sakramentalnej nierozerwalności małżeństwa. A więc uznanie za niewystarczające, aby ukazywać nierozerwalność małżeństwa jako „ideał”, „prawo” czy nawet „wartość”, które to słowa/ znaczenia nie oddają wystarczająco sakramentalnego charakteru związku małżeńskiego. „Nierozerwalność - stwierdza C. Caffarra - nie tyle jest ulokowana we wzajemnym zobowiązaniu wyrażonym w obopólnej zgodzie dwojga, ale w działaniu Boga, który wpisuje znaczenie sakramentalne"6.

5. Problematyczność zasady „wyjątków od reguły”. Jest ona związana z zachwianiem obiektywnych przesłanek, na których opiera się nauczanie Kościoła, a wynikającym ze skontekstualizowania doktryny. Oto jeden z komentarzy wskazujący na takie niebezpieczeństwo: „Jeśli Kościól miałby kiedykolwiek powiedzieć po Synodzie, że potwierdzając nierozerwalność małżeństwa może jednocześnie umożliwić pewne wyjątki udzielania komunii osobom po rozwodzie i w powtórnych związkach, wtedy przeciętny parafianin powie: «Kościół katolicki albo już nie wierzy, że małżeństwo jest nierozerwalne, albo nie wierzy, że cudzołóstwo jest grzechem ciężkim»"?.

6. Osoby rozwiedzione i żyjące w nowych związkach posiadają liczne środki, które - jeśli podjęte $z$ wiarą - mogą doprowadzić rozwiedzionych do wielkiej zażyłości z Chrystusem. Jednakże paradoksalnie dopuszczenie ich do Komunii św. byłoby zaciemnieniem tej zażyłości, której znakiem jest każdy z sakramentów. Osoby rozwiedzione żyjące w nowych związkach mogą owocnie przystępować do komunii duchowej.

7. Argument psychologiczny mówiący, że nie wolno rezygnować z ideału ewangelicznego, tzn. nie wolno tworzyć wrażenia, że chrześcijańskie

$5 \quad$ Por. Cz. S. Bartnik, Komunia dla rozwiedzionych?, „Nasz Dziennik” [z dn. 05.10.2014 r.]

6 C. Caffarra, Sakramentalność ontologiczna a nierozerwalność matżeństwa, [w:] Pozostać w prawdzie Chrystusa. Małżństwo i Komunia w Kościele katolickim, R. Dodaro (red.), Poznań 2015, s. 166.

7 Por. G. E. Murray, Reading the Synod's Final Report, „The Catholic Thing”, [November 2014, 8]. 
małżeństwo i rodzina to droga niemożliwa do zrealizowania, a człowiek skazany jest na błądzenie, pogrążony we własnej niemocy.

8. Wskazanie, że ideał wzajemnej wierności mężczyzny i kobiety nie stracił na atrakcyjności; większość młodych osób tęskni do stabilnego, trwałego związku, odpowiadającego duchowej i moralnej naturze człowieka8 ${ }^{8}$.

\section{Racje zwolenników dopuszczania do Eucharystii}

Przy czym część opowiada się za przyjęciem (w sposób nieuogólniony) do stołu eucharystycznego w niektórych szczególnych sytuacjach i pod konkretnie określonymi warunkami9.

1. W Relatio synodi stwierdza się, że w odniesieniu do osób rozwiedzionych, będących w nowych związkach oraz pragnących uczestniczyć sakramentalnie w życiu Kościoła, należy odnosić się z szacunkiem unikając języka dyskryminacji. Przy tym wskazuje się na nową wrażliwość duszpasterską odnośnie do związków wolnych i niesakramentalnych.

2. Sytuacja związków "nieregularnych” w znacznym stopniu podyktowana jest rozpowszechnioną dziś mentalnością, a także sytuacją egzystencjalną, które nie mają bezpośredniego związu z niechęcią wobec Boga i Kościoła.

3. Zgłasza się potrzebę aggiornamento, aby wierni potrafili zrozumieć i dostosować doktrynę Kościoła do Ewangelii, do teologii, aby znaleźć nowy sposób odkrycia sensu tego, co mówił Jezus Chrystus.

4. Niejako na przedłużeniu poprzedniego argumentu przywołuje się zasadę epikii, a więc możliwości dostosowania nauczania ogólnego do konkretnej sytuacji ${ }^{10}$. Oznacza ona zerwanie $z$ doktrynerstwem, a więc traktowaniem wypowiedzi doktrynalnych jako jedynego kryterium prawdziwości wszystkich niemal sądów teologicznych.

5. W konsekwencji, osąd, na podstawie którego można dopuścić osoby do Komunii św. opiera się przede wszystkim na racjach subiektywnych, na osobistym przekonaniu i osobistej zgodzie sumienia, a nie zewnętrznej normie prawnej.

$8 \quad$ Por. G. L. Müller, Świadectwo mocy laski. O nierozerwalności małżeństwa $i$ debacie dotyczacej dopuszczania do sakramentów osób rozwiedzionych żyjących w nowych zwiąkach, [w:] Pozostać w prawdzie Chrystusa, op. cit., s. 154.

Relatio synodi, nr 52.

10 W formie polemiki z tym poglądem, określanym też „sytuacjonizmem”, należy chyba zaznaczyć, że nawet jeśli nie ma jednego rozwiązania dla wszystkich sytuacji, to domagają się one jednak jednolitej w tym względzie postawy duszpasterskiej. Rozbieżności w sprawach wielkiej wagi przyczyniają się do poważnej dezorientacji wiernych. Por. T. Makowski, Pastoralny aspekt spowiedzi matżonków, [mps], s. 208. 
6. Podnosi się rację, iż nie ma takiej ludzkiej sytuacji, która byłaby całkiem bez wyjścia i odarta z nadziei. Jakkolwiek nisko upadł człowiek, nie spadnie niżej, niż sięga Boże miłosierdzie. Dramatyzm sytuacji osób opisuje się na sposób metafory „dziury”, w którą się wpada i z której nie ma już wyjścia. Pogląd ten podtrzymuje się argumentem, iż jedynie grzech przeciwko Duchowi Świętemu jest nieodpuszczalny, każdy inny może być odpuszczony ${ }^{11}$.

7. W większości sytuacji praesumptio iuris (domniemanie prawne), z której wywodzi się prawo kościelne, jest fictio iuris (fikcją prawną) $)^{12}$.

8. Model życia „jak brat z siostrą”, wymagany przez kościelne uregulowania, może być potraktowany jako sprowadzenie wspólnoty małżeńskiej do dzielenia łoża, a współżycie płciowe do kryterium małżeńskiej rzeczywistości. Prowadzi on w ostateczności do „seksualizacji” złożonej i dramatycznej sytuacji osób rozwiedzionych.

9. Wskazuje się na możliwość przyjęcia okresu pokuty jako nowej szansy - w tym sensie byłoby to zbliżenie do praktyki prawosławnej. Mówi się o tzw. teologii ekonomii, jako umiejętnej sztuce ,zagospodarowywania terenu". Oznacza ona zerwanie $z$ doktrynerstwem, rygoryzmem oraz legalizmem, a więc postawą ograniczającą się do bezdusznej apologetyki zasad moralnych, skrupulatnego precyzowania ich sensu bez wysiłku wnikania w konkretną sytuację.

10. Relacje biblijne dotyczące nierozerwalności małżeństwa tłumaczy się jako historyczne modyfikacje w pierwszej gminie wywołane trudnościami ewangelizacyjno-duszpasterskimi oraz społecznymi uwarunkowaniami kobiet $^{13}$.

11. Wizja Eucharystii jako „lekarstwa”, które nie jest nagrodą za cnotliwe życie dla niektórych.

Nie wdając się w szczegółowy komentarz odnośnie do każdego z przywołanych tylko reprezentatywnie argumentów, wydaje się, że kluczowe - przynajmniej z punktu widzenia autora tekstu - jest rozstrzygnięcie pytania, na ile jedna i druga opcja rozumie obecny stan refleksji jako impas, a na ile impuls. Przy czym, tzw. opcja zachowawcza, spoglądająca „wstecz” nie powinna być zwyczajnie kojarzona $z$,impasem”, a opcja progresywna widziana jako ta

11 Czy „grzech przeciwko Duchowi Świętemu” można jednak interpretować na poziomie moralnym, jako jeden z katalogu grzechów ujętych normatywnie? Wiadomo, że jego teologiczne znaczenie jest o wiele głębsze.

12 Por. W. Kasper, Das Evangelium von der Familie: Die Rede von dem Konsistorium, Freiburg im Breisgau 2014.

13 Por. W. Hryniewicz, Blask mitosierdzia, [Biblioteka „Tygodnika Powszechnego”], Kraków 2015. 
szukająca jedynie „impulsu”. W jednej i drugiej może ukrywać się rzeczywiste niebezpieczeństwo myślenia zideologizowanego, prowadzącego do „impasu”, jak i szansa widzenia czegoś dalej i szerzej, a więc impuls do pogłębionej i bardziej odpowiedzialnej refleksji. Wskazać by można na przynajmniej trzy pola, na których możemy mieć do czynienia zarówno z impasem jako i impulsem.

\section{Zagadnienie miłosierdzia}

W debacie wielokrotnie przewija się wątek „miłosierdzia”, przypominający Kościołowi, który jest sakramentem zbawienia dla wszystkich ludzi, że winien wyjść naprzeciw tym, którzy pragną się nawrócić i żyć Ewangelią. Wnikając jednak głębiej w powyższą retorykę pojawia się wrażenie jego pewnego zinstytucjonalizowania. Na poziomie debat tworzy się nieco wyimaginowaną linię demarkacyjną: kto jest tym miłosiernym, a kto rygorystą. Kategoria ta bywa nadużywana i mylnie interpretowana jako schlebianie słabości, czy kierowanie się logiką współczucia. Teologicznie rzecz biorąc, nie sposób zrozumieć postawę miłosierdzia, na sposób gestis verbisque Chrystusa bez związku z najbardziej elementarnym poszanowaniem porządku sprawiedliwości oraz powagi sytuacji, w jakiej znalazł się grzesznik. Owszem, Chrystus szuka tego, co się zagubiło. Szuka przez wiarę (pytając o wiarę), przez miłość (która uzdrawia), ale czyni to głosząc Królestwo Boże, które musi nadejść. Głosi sąd nad ludzkim grzechem, aby mogła objawić się sprawiedliwość Boża. Żeby mogła objawić się prawda miłości, musi zostać osądzone to, co jest źródłem kłamstwa. Nieposłuszeństwa ludzi i całego zła historii Bóg nie może tak po prostu wymazać, puścić w niepamięć, ani też potraktować bez powagi. Taki rodzaj miłosierdzia i bezwarunkowego przebaczenia byłby tanią łaską. Niesprawiedliwości i zła nie można ignorować i tolerować. Muszą być one przeobrażone i pokonane jako właściwy i jedyny sposób objawienia autentycznego miłosierdzia. Stąd w kontekście naszego problemu, nieskromny osąd o brak miłosierdzia z jednoczesnym lekceważeniem krzywd wyrządzonych ofiarom prowadzi na manowce. Czy otwieramy przestrzeń dla miłosierdzia Bożego, minimalizując doświadczenie klęski i upadku? Czy jesteśmy gotowi na odpowiedź: jak sobie radzić dalej pomimo upadku?

\section{Problematyka grzechu}

Nierozerwalnie z problemem osób rozwiedzionych żyjących w nowych związkach wiąże się zagadnienie grzechu. Ocenę odpowiedzialności moralnej sytuacji tych osób podjęto w oparciu o katechizmowe kryteria czynu: materia ciężka, świadomość i dobrowolność. Pojawia się jednak pytanie, czy tego rodzaju podejście wnosi coś istotnego do problematyczności zagadnienia? 
Tok rozumowania idzie też po linii możliwych warunków udzielenia absolucji w ramach sakramentu pokuty. Jeśli jednak weźmie się pod uwagę liczne interpretacje Mateuszowej perykopy o władzy „wiązania” i „rozwiązywania”, konstytutywnej dla rozumienia absolucji, wtedy poziom argumentacji radykalnie się zmienia. Można bowiem mówić o przynajmniej czterech interpretacjach: jurydycznej, filologicznej, demonologicznej, eklozjologiczno-kerygmatycznej. Symptomatyczna jest ostatnia, mówiąca o władzy wspólnoty, na mocy której wyklucza się grzesznika z pełnego uczestnictwa w życiu wspólnoty (zwłaszcza eucharystycznej) i ewentualne przyjęcie go z powrotem, po wypełnieniu odpowiednich warunków. W punkcie wyjścia podejmowanego problemu znajdują się: zasadnicza kwalifikacja omawianego grzechu oraz określenie licznych jego uwarunkowań, nie zaś normatywne rozstrzygnięcie, odwołujące się do kryteriów czynu czy warunków absolucji. Punkt ciężkości leży zatem w działaniu bardziej odpowiedzialnym, polegającym na przedstawieniu przyczyn i motywacji związanych z ludzką grzesznością. Współczesne nauki o człowieku wydobyły szereg uwarunkowań, które uzasadniają pytanie: na ile mamy do czynienia z winą jako całkowicie wolną decyzją człowieka, a na ile jest ona uwarunkowana? Istnieją bowiem tysiące przyczyn wynikających z wrodzonych predyspozycji, środowiska społecznego, cech dziedzicznych, chybionego wychowania, nacisku opinii publicznej, ograniczoności naszych motywacji ${ }^{14}$. Rzeczywiste zło winy wobec Boga może się ukrywać za czymś, co pozornie dobre, za niewinnymi błahostkami. A zarazem, pozornie nieszkodliwy kierunek rozwoju osobowego może być pozornie nieszkodliwą fasadą, kryjącą w mglistej decyzji życiowej rzeczywistą winę ${ }^{15}$. Warto tę kwestię przemyśleć szerzej w kontekście przygotowania i prowadzenia osób wybierających drogę małżeńską, jak i mądrego towarzyszenia tym, którzy już doznali na niej porażki.

\section{Prawo wzrostu}

Miłość doświadczana jako pełnia nie jest jednak pełnią całkowitą, jest stale zagrożona przez egoizm. Nierzadko staje się raczej kierunkiem, niż przebytą drogą, gdyż takiej miłości towarzyszą czasem inne moce równie silne, które ograniczają jej ruch. Bowiem nagle to, co miało być dozgonne, definitywne i wieczne, jako odbicie miłości Boskiej, ochładza się, staje się dziwnie obce. W każdej jednak miłości tkwi głęboka tęsknota za miłością doskonałą. W tym kontekście

$14 \quad$ Ze stwierdzeniem tym zdaje się zgadzać papież Franciszek, wspominając o stanie obecnej wiedzy na temat okoliczności o charakterze psychologicznym, historycznym, a nawet biologicznym, które mogą wpłynąć na decyzje człowieka, który dopuszcza się jakiegoś zła. Por. AL 308.

15 Por. K. Rahner, Sakramenty Kościoła, tł. J. Zychowicz, Kraków 1997, s. 60-64. 
istotna wydaje się zasada stopniowości ${ }^{16}$ polegającą na tym, że małżonkowie odkrywają tajemnicę małżeństwa stopniowo, etapami urzeczywistniają ideały, do których dążą ${ }^{17}$. W każdym nawet najbardziej udanym związku małżonkowie narażeni są na realne ryzyko porażki. Oznacza to, że pewien projekt na życie, ze wszystkimi swoimi nadziejami upada. Upadek stanowi jednak część biblijnej teologii Przymierza. Realistyczna teologia małżeństwa musi uwzględniać taką sytuację oraz możliwość przebaczenia. Nawet w sytuacjach, gdy nie widzimy drogi wyjścia albo dostrzegamy tylko jedno możliwe rozwiązanie, Bóg może wskazać zupełnie nowe, nieprzewidywalne.

\section{Odniesienie do konkretnych doświadczeń}

Rzetelna refleksja nad powyższymi kwestami domaga się z jednej strony jasności doktrynalnej oraz jednolitej w tym względzie postawy duszpasterskiej, z drugiej zaś - musi uwzględniać całą złożoność życia i sytuacji, których nie da się ująć w schematy. Niemożliwe jest wypracowanie gotowych rozwiązań, definitywnych i wiążących w każdej sytuacji, dających zawsze pozytywne rezultaty i zwalniających nas od odpowiedzialnej refleksji. Przed teologią ciągle stoi zadanie wypracowania procedur pozwalających na wzajemne przenikanie się teorii oraz praxis. Myślenie i działanie to jedna sztuka odpowiedzialnego życia z innymi w epoce nadmiaru instytucji. Sztuki tej należy się uczyć poprzez nieustanny wysiłek refleksyjnego podejścia do wszystkiego, co się wydarza w człowieku, w jego relacjach, w świecie. Ten fronetyczny (phronesis) model uprawiania teologii, odpowiada współczesnym oczekiwaniom, aby ich wyniki badań, spostrzeżenia, analizy, wnioski, sugestie, a więc cały ich potencjał intelektualny miał jak najszerszy rezonans w codzienności.

\section{Horyzont refleksji nad sakramentalnością małżeństwa w relacji do Eucharystii}

Liczne badania pokazują, że małżeństwo uważane było zawsze za magnum misterium, za wspólnotę o charakterze religijnym przede wszystkim z racji wpisanej w nie tajemnicy miłości i mocy stwarzania nowego życia. Pierwsze wersety Księgi Rodzaju dowodzą, że stworzony przez Boga związek mężczyzny

$16 \quad$ Familiaris consortio 9, 34.

17 Ku takiemu stanowisku skłania się papież Franciszek, który w kilku miejscach adhortacji (38, 122, 195), mówi o prawie wzrostu i stopniowości procesu, jakim jest małżeństwo. „Nie jest to «stopniowość prawa», ale stopniowość w roztropnym wypełnianiu wolnych aktów w podmiotach, które nie są w stanie zrozumieć, docenić lub w pełni realizować wymogów prawa”. AL 295. 
i kobiety jest najdoskonalszym obrazem relacji Boga z ludźmi. Charakter tego znaku sprawia, że małżeństwo otwiera się na transcendencję, a zarazem całym sobą ją wyraża. „Małżeństwo - stwierdza Franciszek - to cenny znak, bo „kiedy mężczyzna i kobieta zawierają sakrament małżeństwa, Bóg niejako «odzwierciedla się» w nich, nadaje im własne rysy i niezatarty charakter swojej miłości. Małżeństwo jest ikoną miłości Boga do nas"18. Ta podstawowa struktura znakowości małżeństwa rzeczywiście pozwala nam powiedzieć, że sakrament małżeństwa jest „najpierwotniejszy” i w tym sensie otwiera horyzont refleksji teologicznej.

Tło, a właściwiej będzie powiedzieć - horyzont niniejszej refleksji stanowi rozumienie sakramentalności małżeństwa, które jest immanentnie zakorzenione w naturze związku mężczyzny i kobiety i jako takie wyraża nienaruszalną wartość, jak również możliwość doświadczenia transcendencji. Przekaz biblijny jest tutaj jednoznaczny i niepodlegający jakiejkolwiek dyskusji: akceptacja stworzonego związku mężczyzny i kobiety jest obrazem związku Boga z ludźmi ( $\mathrm{Rdz} 1,26-31)$. Dalej, współistnienie z drugim - właśnie (i wyłącznie) mężczyzny i kobiety, umożliwia wspólistnienie Boga z człowiekiem. Perspektywa ta wyznacza antropologiczno-teologiczne ramy dla rozumienia sakramentalności, jako żywej i skutecznej obecność Boga w ludzkim życiu. Jednocześnie koncentruje naszą uwagę na dwóch szczególnych znakach tej obecności: Eucharystii i małżeństwie, które w równym stopniu są „odwzorowaniem Boga”, Jego wiernej miłości, a także sposobem realizacji Jego Przymierza z ludźmi, które swoją najpełniejszą i najbardziej namacalną formę osiągnęło w relacji Chrystusa do Kościoła (por. Ef 5, 21). Naruszenie podstawowej struktury owej znakowości, pociąga konsekwencje nie tyle w sferze prawno-moralnej, co teologiczno-ontologicznej, zamazując w ten sposób biblijny obraz Boga, zniekształca podstawowy sens Zbawienia i cel człowieka.

Co zatem wynika dla owej refleksji z punktu widzenia struktury sakramentu? Przede wszystkim to, iż znaku sakramentalnego (signum) nie można już dłużej traktować mechanicznie, rytualnie i legalistycznie, z drugiej - chodzi o pogłębienie świadomości, że znak ten niesie ze sobą rzeczywistość (res), wpływa na wyobraźnię, kształtuje nasze myślenie. Największy dramat w życiu człowieka ma miejsce wtedy, gdy rozbijamy jedność tego, co na powierzchni od tego, co ukryte i tajemnicze. Podobnie dzieje się na gruncie sakramentologii, owo rozbicie stanowi podstawowe źródło sakramentalnego dramatu. Niestety, także w debacie okołosynodalnej na temat małżeństwa dominowało myślenie kategorialno-funkcjonalne, odzwierciedlające ową dramatyczność sytuacji. Dyskusja wielokrotnie była/jest sprowadzona do kazuistyki, manipulującej signum, nie 
dotykając jednakże esencji (res), która musi być gruntownie przemyślana. Mówienie o sakramencie sprowadza się najczęściej do warstwy znaczeniowej, gestu liturgicznego, obrzędu, przykazania. Ujmując to najzwięźlej: zatrzymujemy się na tym co powierzchowne, doraźne i poddane łatwej kalkulacji (signum), a umyka nam res, jako to strasznie wymagające, bo uprzystępniające sens i siłę nazwania signum. Tak więc mamy dwie nierozdzielne płaszczyzny: signum i res. Ta współzależność, a dokładniej jej niezrozumienie zawsze rodziły i nadal rodzą w praktyce duszpasterskiej napięcia i nieprawidłowości (urzeczowienie, automatyzm, formalizm, powierzchowność, magiczność). Jakie znaczenie ma powyższa charakterystyka, tak oczywista w zakresie de sacramentalis in genere, wpływ na na rozumienie sakramentalności małżeństwa?

Teologiczny wgląd $w$ istotę małżeństwa od samego początku wskazuje, że jego naturalne elementy: miłość, wyłączność i nierozerwalność, cielesność, akt woli, nie są jedynie warunkami przyjęcia sakramentu, ale stanowią istotną strukturę znaku sakramentanego ${ }^{19}$. Małżeństwo sakramentalne jest zatem znakiem nierozerwalności, wierności, przymierza i otwartości na życie ${ }^{20}$, gdzie każdy z tych konstytutywnych elementów na zasadzie obrazu i uczestnictwa ma swoje odniesienie do Boga. Nierozerwalność stanowi obraz woli Bożej, wierność - jest obrazem miłości, otwartość zaś - oznacza udział w życiu Boga ${ }^{21}$. Życie może bowiem podarować jedynie Ten, który sam jest życiem! „Para, która kocha i rodzi życie, jest prawdziwą żywą «figurą» (ale nie żadną z tych wykonanych z kamienia lub złota, jakich zakazuje Dekalog), zdolną ukazać Boga Stwórcę i Zbawiciela. Dlatego płodna miłość staje się symbolem intymnej rzeczywistości Boga. W tym świetle owocne relacje małżonków stają się obrazem, służącym do odkrycia i opisania tajemnicy Boga kontemplowanej przez chrześcijan poznających w Trójcy Świętej Boga Ojca, Syna i Ducha miłości”22. Miłość - wierność - życie to triada, nie tylko oznaczająca i wyrażająca Boga w jego relacji człowieka: mężczyzny i kobiety, ale klucz ich wzajemnego współistnienia. W świetle powyższego, jakiekolwiek zamazanie znaku małżeńskiego wiąże się nie tylko ze sprzeniewierzeniem się woli Bożej, wykroczeniem moralnym, ale

19 Por. Cz. Rychlicki, Sakramentalny charakter przymierza matzeńskiego, Płock 1997, s. 361.

20 Papież Franciszek definiuje sakrament następująco: „Małżeństwo chrześcijańskie, będące odzwierciedleniem jedności między Chrystusem a Jego Kościołem, realizuje się w pełni w jedności mężczyzny i kobiety, którzy oddają się sobie nawzajem w wyłącznej miłości i dobrowolnej wierności, należą do siebie aż do śmierci i są otwarci na przekazywanie życia, uświęceni sakramentem, który udziela im łaski, aby stawali się Kościołem domowym i zaczynem nowego życia dla społeczeństwa”. AL 292

21 Por. M. Healy, Mężczyźni i kobiety są w raju, tł. J. Jaworska, [seria: „Teologia ciała” Centrum JP 2], Warszawa 2008, s. 93. 
przede wszystkim zaprzeczeniem prawdy o Bogu; zanegowaniem podstawowego przesłania o Jego oblubieńczej miłości do ludu, do Kościoła.

W świetle powyższego, kluczowa staje się symbolika wyrażona w biblijnym: „oboje będą jednym ciałem” (Rdz 2,24), która sama posiada strukturę symbolu. Sformułowanie „oboje będą jednym ciałem” wyraża cielesne powiązanie, ale obejmuje znacznie więcej - bo związek całoosobowy. W świetle $\mathrm{Rdz}$ 2, 24 należy też interpretować fragment „Stworzył ich jako mężczyznę i kobietę” (Rdz 1, 27). Interpretacja ta wskazuje, że Bóg stworzył ich jako jednego mężczyznę i jedną kobietę i powołany do istnienia związek w czasie stworzenia dwojga ludzi Bóg rozumiał jako nierozerwalną wspólnotę 23 . W symbolice „cielesności” wybrzmiewa jeszcze jeden aspekt. Otóż cielesność, jako „widzialna” męskość i kobiecość, staje się zdolna, aby uczynić widzialnym to, co niewidzialne: duchowe i Boże. Cielesność jest stworzona, aby przenosić w widzialną rzeczywistość świata ukrytą odwiecznie w Bogu tajemnicę, aby być właśnie jej znakiem²4. Ten moment można uznać chyba za rewolucyjny: człowiek jako obraz Boży ma wyrażać i objawiać samym sobą treści znaczeniowe niepochodzące z tego świata jako symbol Przymierza między Stwórcą i stworzeniem.

Symbolika ta zyskuje swoją konkretności w nauce św. Pawła. Nawiązując do $\operatorname{Rdz} 2$ 2,24, do wizji „,jednego ciała”, Apostoł dostrzega tam klucz i podstawę rozumienia małżeństwa jako odtworzenia relacji miłości Chrystusa do Kościoła. Ład naturalny zostaje przeniknięty Odkupieniem Jezusa Chrystusa. „Porządek Odkupienia - stwierdza Franciszek - oświeca i dopełnia porządek stworzenia. Zatem małżeństwo naturalne można do końca zrozumieć w świetle jego sakramentalnej pełni: tylko wpatrując się w Chrystusa można dogłębnie poznać prawdę o relacjach międzyludzkich"25. Odtąd małżeństwo jako sakrament „najpierwotniejszy” ma być włączone w Jego zbawcze dzieło. Łaska sakramentalna, której udziela Chrystus, jawi się przede wszystkim jako osobowa więź z Chrystusem i Duchem Świętym, dzięki której naturalny związek miłości między nimi zostaje wyniesiony i udoskonalony do iście Boskich rozmiarów. Od tego momentu w życiu i historii małżonków nic nie podlega (przynajmniej: nie musi już podlegać) fatalizmowi, nic nie jest niewybaczalne, niemożliwe do naprawienia, nieuleczalne. Podczas gdy gdzie indziej, wszystko mówi, że istnieje nieuchronność, sakramentalna obecność Chrystusa w ich życiu sprawia, że odtąd niemożliwe mogą uznać za możliwe. Znamienne, że Chrystus nie ustanawia nowego znaku sakramentalnego, lecz cały nacisk chce

\footnotetext{
23 Por. R. Bartnicki, Nauka Jezusa onierozerwalnościmalżeństwaw Mk 10, 1-12, „Warszawskie Studia Teologiczne" 26(2013), 1, s. 26.

24 Jan Paweł II, Mężczyzna i niewiasta stworzyt ich, T. Styczeń (red.), Lublin 1998, s. 237

25 AL 77.
} 
położyć na odrzucenie tego wszystkiego, co było wypaczeniem pierwotnej myśli Stwórcy, co wkradło się w małżeństwo jako owoc „zatwardziałości serc” (Mt 19,5) 26. W ten sposób przywraca On i potwierdza ów pierwotny charakter sakramentu. Sakramentalność małżeństwa zakorzeniona jest więc w tajemnicy stworzenia - ostatecznie zaś w tajemnicy zjednoczenia się z Chrystusa z oblubienicą (Kościołem), w tajemnicy Paschy Chrystusa, w Jego ofiarnej Śmierci dla oblubienicy i Zmartwychwstaniu.

W tej perspektywie, znakiem niosącym orędzie Odkupienia i zawarty w nim etos jest ,jedno ciało” jako symbol nasączający teologiczną doniosłość sakramentu. Traci on swoje teologiczne, ale i egzystencjalne znaczenie, jeśli zostaje zerwany. Istnieją dziś opinie teologów, że tego typu symboliczno-estetyczny charakter uzasadniania znaczenia sakramentu nie posiada nośności teologicznej ${ }^{27}$. Dlatego trzeba dziś pogłębić rozumienie symbolu w jego egzystencjalnym odniesieniu. Wydaje się, że wielu (nie pomijając teologów) zagubiło ową zdolność podążania w głąb symbolu, który - mówiąc za P. Ricoeurem - „daje nam do myślenia”. Czy w tym kontekście, argumentacja oparta na jedności symbolu (,jedności obojga”) jest wystarczająca? Czy w horyzoncie planu zbawczego Boga (misterion), który przejawia się w różnych formach i zakresach (choćby wspomnieć problem uniwersalizmu Zbawienia, konieczności znaku sakramentalnego) symboliczno-estetyczny charakter dowodzenia sakramentalności małżeństwa nie zawodzi? Stąd pilnym zadaniem współczesnej teologii sakramentu małżeństwa jest nowe wniknięcie w sferę symboliki zapośredniczajacej prawdę objawioną. Refleksji tej musi towarzyszyć większe niż dotąd dążenie do przywrócenia realizmu w znaczącym i symbolicznym działaniu sakramentalnym. Podejście funkcjonalne i kalkulacyjne, a zwłaszcza jurydyczno-legalistyczny sposób uzasadnienia rangi sakramentu (symbolu) jest dziś już nieskuteczny, a nawet szkodliwy. Dalej, konieczna jest próba antropologicznego wyjaśnienia symbolicznego wydarzenia sakramentalnego, jego języka w odniesieniu do podstawowych sytuacji, węzłowych punktów życia małżonków, ich społecznej egzystencji. Wykazanie, że Bóg w zbawczym działaniu nie pomija naturalnego wzorca symbolicznej interakcji, lecz korzysta z niego, to znaczy, że realizuje dzięki niemu swoje Zbawienie, jednocześnie ów wzorzec transcendując. Ostatecznie chodzi o to, abyśmy w nowej sytuacji odpowiedzieli sobie na pytanie,

26 „Zatwardziałość serca” oznacza, że stało się ono nieczułe wskutek ciągłego nieposłuszeństwa. Bóg dopuszcza tę sytuację nie dlatego, że taka jest Jego wola, ale z powodu grzeszności człowieka, akceptując jego wybór. Zatwardziałość serca jest więc najcięższym grzechem i dlatego jest bliska grzechowi przeciwko Duchowi Świętemu - wiąże się z odrzuceniem Boga i Jego woli.

27 Por. P. Zulehner, Wiederverheiratet, „Stimmen der Zeit” (1995) 120, s. 75-88. 
czym jest i jak winna się wyrażać sakramentalna „konkretyzacja” egzystencji Chrystusa w życiu małżonków.

W świetle poczynionej refleksji można próbować uchwycić (symboliczno-teologiczny) związek między sakramentem małżeństwa i Eucharystii, aby następnie „ferować” jakieś rozwiązania o charakterze praktyczno-dyscyplinarnym. Także tutaj funkcjonuje prymat „logosu” nad „etosem”. Istnieją przynajmniej cztery możliwe pola, na których owa korelacja (pogłębiona teologicznie) stwarza taką szansę. Niech będą one jednocześnie podsumowaniem poczynionej refleksji.

\section{Wymiar oblubieńczy}

Za każdym razem, kiedy uczestniczymy w Eucharystii odnawiamy całkowity dar Chrystusa złożony dla nas na krzyżu oraz naszą odpowiedź w miłości i wdzięczności. Oblubieńczość ta wyraża się nadzwyczaj specyficznie w sakramencie małżeństwa. Przez małżonków Chrystus pragnie widzialnie (sakramentalnie) obwieścić wspólnocie zbawionych swoje pragnienie zaślubin ludzkości. Miłość, wierność, radość, oddanie i ofiarność małżonków zostają włączone („wszczepione”) w Jego nieskończoną miłość (wyrażoną i objawioną najpełniej w Eucharystii) i dopiero od tej chwili stają się one w pełni, bez zastrzeżeń możliwe, nie prowadząc do okaleczenia ich osobowości, ponieważ miarą dla ich postępowania staje się Chrystus ${ }^{28}$. Dzięki Eucharystii w życiu małżonków zaczyna się i dopełnia droga „nasycania się życiem Chrystusa”, uczenia się od Niego i odzwierciedlania Jego stylu bycia. Oba te sakramenty można rozumieć w ich wymiarze oblubieńczym ${ }^{29}$, w których ludzka miłość oblubieńcza jest powołana do tego, aby upodobnić się do miłości Boga i ostatecznie w niej się wypełnić. Oba sakramenty pozwalają nawzajem się zrozumieć: eucharystyczna miłość jest bezgraniczna, jak tego może pragnąć najgłębsza miłość oblubieńcza (małżeńska).

\section{Wymiar duchowy}

W adhortacji Familiaris consortio wielokrotnie pojawiają się stwierdzenia: „nowe”, „wzbogacenie”, „wyniesienie”, „wywyższenie”, „podniesienie”, „oczyszczenie”, „uświecenie”. Jest też mowa o „nowym sercu” jako darze Ducha Świętego. W Eucharystii najpełniej Chrystus wylewa na człowieka swojego Ducha;

28 Por. R. Martin, N. Martin, Sakrament matżeństwa jako trójprzymierze a Eucharystia, [w:] Jan Paweł II, Mężczyzna i niewiastą stworzyt ich, T. Styczeń (red.), Lublin 1998, s. 303.

29 Franciszek pisze: „Przyjmując siebie nawzajem i za łaską Chrystusa, nowożeńcy przyrzekają sobie całkowite wzajemne oddanie, wierność i otwartość na życie. Za elementy konstytutywne małżeństwa uznają oni dary, jakimi obdarza ich Bóg, podejmując na serio swoje wzajemne zobowiązanie, w Jego imię i wobec Kościoła”. AL 72. 
każda Eucharystia to „mała Pięćdziesiątnica”. W ten sposób małżonkowie doświadczają najgłębszego uduchowienia swojej ludzkiej miłości na wzór Boga. Ponadto Chrystus przez swojego Ducha odwzorowuje w małżonkach życie, jakie pokazał w Ewangelii. Małżonkowie przyjmują nowy sposób miłowania, nie tyle na sposób cnotliwego realizowania swojej afektywności, co przez przyjęcie nowej zdolności kochania, ofiarowanej im przez Ducha Świętego. Na miarę Chrystusa potrafią „umrzeć” dla siebie w ludzkim sposobie kochania ${ }^{30}$. Doskonale oddają tę dynamikę słowa Franciszka: „Miłość, ze względu na swój charakter, nie ma nic takiego, co ograniczałoby jej rozwój, ponieważ jest ona udziałem w nieskończonej miłości, którą jest Duch Święty”31.

\section{Wymiar komunijny}

Małżeństwo kobiety i mężczyzny jawi się jako najgłębsza możliwa relacja osób. Pomiędzy małżonkami powstaje zobowiązujące małżeńskie „my”, możliwość przekroczenia samego siebie ku drugiemu. I znów, to Eucharystia tworzy nowe „my”, w świetle którego zaczynamy oceniać rzeczywistość według kryterium Chrystusa. Małżeństwo zostało określone przez Jana Pawła II jako communio personarum, czyli jako „komunia osób”, będąca pełnym darem jednej dla drugiej, a razem odniesionych ku Bogu. „Jest to miłość, która jednoczy małżnków , uświęcona, ubogacona i oświecona łaską sakramentu małżeństwa. Jest to «zjednoczenie woli», duchowe i ofiarne, które jednak zawiera w sobie czułość przyjaźni i namiętność erotyczną, chociaż jest w stanie przetrwać nawet wtedy, gdy uczucia i namiętność ulegają osłabieniu"32. Małżeństwo to związek nie tylko cielesny czy tylko emocjonalny, lecz przede wszystkim całoosobowy: umysłowy, duchowy, moralny, społeczny i twórczy, niejako związanie dwóch światów w jeden, z zachowaniem oczywiście swoich właściwości, zadań, cech, godności i wolności.

\section{Wymiar przymierza}

Małżeństwo stanowi trójprzymierze z Bogiem Ojcem, Synem i Duchem Świętym. Celem stworzenia jest przymierze. W Starym Testamencie miłosna więź między mężczyzną a kobietą tworząca „jedno ciało” staje się obrazem i znakiem Przymierza Boga z Jego ludem ${ }^{33}$. Przymierze to opiera się na wiecznej

30 Por. J. Nagórny, Małzeńskie przymierze miłości, [w:] Jan Paweł II, Mężczyzną i niewiasta stworzyt ich, op. cit., s. 229.

31 AL 134.

32 AL 120.

33 Familiaris consortio 12. 
milości Boga (hesed), na wierności (emunah), a nawet na zazdrości (qinah), czyli dokładnie tak samo, jak przymierze małżeńskie. Niewierność ludu wobec Boga określana jest cudzołóstwem, jest odrzuceniem miłości oblubieńczej Pana. „Kobieta mojego przymierza” (Ml 2, 14) znaczy: „moja żona”. Małżeństwo jest przymierzem, a przymierze jest małżeństwem - obie kategorie się wzajemnie interpretują. Komunia Boga z ludźmi, czyli Przymierze, znalazła ostateczne urzeczywistnienie w Jezusie Chrystusie - osobowym Przymierzu. W Jezusie Chrystusie Bóg wypowiedział swoje definitywne „tak” wobec ludzkości. Przymierze to ma charakter osobowy, obustronny i dialogiczny, ponieważ miłość Chrystusa jest tak potężna, iż jest zdolna obudzić w człowieku wolną odpowiedź miłości. Uzdolniła ona człowieka do bycia partnerem w Przymierzu z Bogiem. I znowu, rys ten najwyraźniej ukazuje właśnie Eucharystia jako pamiątka Nowego i Wiecznego Przymierza we Krwi Chrystusa. „Eucharystia - stwierdza Franciszek - jest sakramentem Nowego Przymierza, w którym dokonuje się odkupieńcze działanie Chrystusa (por. Łk 22, 20). W ten sposób można dostrzec głębokie więzi między życiem małżeńskim a Eucharystią. Pokarm Eucharystii jest siłą i inspiracją, aby przeżywać każdego dnia przymierze małżeńskie jako „Kościół domowy”34.

W kontekście Eucharystii jako znaku urzeczywistniającym obecność osobową Chrystusa w życiu człowieka, małżonków, wymiar duchowy, osobowy i komunijny w pojmowaniu małżeństwa oraz sposobie zaradzenia dzisiejszym trudnościom, należy uznać za kluczowy. To przecież w Eucharystii uczymy się Chrystusowego stylu życia, czyli tego, o co ostatecznie chodzi w przė̇ywaniu sakramentu małżeństwa, nie wykluczając miłosierdzia, ofiary. Istnieje stąd pilna potrzeba pogłębienia tematyki duchowości małżeńskiej, opartej na dogmatyce. Podmiotem tak rozumianej duchowości małżeńskiej jest Duch Święty. Chodzi o: ukazanie mistycznego powołania sakramentalnego małżeństwa, dalej wymiaru duchowego, który jest fundamentem moralności. W końcu o nowe opisanie teologii komunii małżeńskiej oraz jej związku z komunią eklezjalną i sakramentalną.

Słowa kluczowe: małżeństwo, sakrament, Eucharystia, Franciszek, Synod.

\section{Bibliografia:}

1. Bartnicki R., Nauka Jezusa o nierozerwalności małzeństwa w Mk 10, 1-12, „Warszawskie Studia Teologiczne" (2013) 26, 1, s. 11-30.

2. Bartnik Cz. S., Komunia dla rozwiedzionych?, „Nasz Dziennik” [z dn. 05.10.2014 r.]

$34 \quad$ AL 318. 
3. Caffarra C., Sakramentalność ontologiczna a nierozerwalność matżeństwa, [w:] Pozostać w prawdzie Chrystusa. Matżeństwo i Komunia w Kościele katolickim, R. Dodaro (red.), Poznań 2015.

4. Healy M., Mężczyźni i kobiety są w raju, tł. J. Jaworska, [seria: „Teologia ciała” Centrum JP 2], Warszawa 2008.

5. Hryniewicz W., Blask mitosierdzia, [Biblioteka „Tygodnika Powszechnego”], Kraków 2015.

6. Jan Paweł II, Mężczyzna i niewiasta stworzyt ich, T. Styczeń (red.), Lublin 1998.

7. Kasper W., Das Evangelium von der Familie: Die Rede von dem Konsistorium, Freiburg im Breisgau 2014.

8. Makowski T., Pastoralny aspekt spowiedzi matżonków, [mps], s. 199-211.

9. Martin R., Martin N., Sakrament matżenstwa jako trójprzymierze a Eucharystia, [w:] Jan Paweł II, Mężczyzna i niewiasta stworzyt ich, T. Styczeń (red.), Lublin 1998, s. 299-314.

10. Murray G. E., Reading the Synod's Final Report, „The Catholic Thing”, [November $8,2014]$.

11. Müller G. L., Nie można mieć dwóch żon, http://ekai.pl/wydarzenia/komentarze/ x87756/kard-muller-nie-mozna-miec-dwoch-zon/?print=1. [dostęp: 28.04.2016].

12. Müller G. L., Świadectwo mocy łaski. O nierozerwalności matżeństwa i debacie dotyczacej dopuszczania do sakramentów osób rozwiedzionych żyjacych w nowych zwiazkach, [w:] Pozostać w prawdzie Chrystusa. Matżenstwo i Komunia w Kościele katolickim, R. Dodaro (red.), Poznań 2015, s. 143-159.

13. Nagórny J., Matżénskie przymierze miłości, [w:] Jan Paweł II, Mężczyzną i niewiasta stworzyt ich, T. Styczeń (red.), Lublin 1998, 207-230.

14. Rahner K., Sakramenty Kościoła, tł. J. Zychowicz, Kraków 1997.

15. Relatio synodi, III Nadzwyczajnego Zgromadzenia Ogólnego Synodu Biskupów, http:/episkopat.pl/dokumenty/6230.1,quot_Relatio_Synodi_quot_III_Nadzwyczajnego_Zgromadzenia_Ogolnego_Synodu_Biskupow.html. [dostęp: 28.04.2016].

16. Rychlicki Cz., Sakramentalny charakter przymierza małżénskiego, Płock 1997.

17. Zulehner P., Wiederverheiratet, „Stimmen der Zeit” 120(1995), s. 75-88. 